\title{
INSULIN SECRETAGOGUE EFFECT OF ROOTS OF RAVENALA MADAGASCARIENSIS SONN. - AN IN VITRO STUDY
}

\author{
SAKTHI PRIYADARSINI S*, KUMAR PR, ABHISHEK ANAND, DEVENDIRAN B, VENKAT S KADIYAM, \\ RICHIE PADMANABH ROY
}

Department of Pharmacognosy, SRM College of Pharmacy, SRM Institute of Science and Technology, Kattankulathur, Tamil Nadu, India. Email: sakthivendan@gmail.com

Received: 09 September 2018, Revised and Accepted: 11 October 2018

ABSTRACT

Objective: The objective of this study was to establish the cytotoxicity profile and to evaluate the insulin secretagogue effect of ethanolic root extract of Ravenala madagascariensis Sonn.

Methods: The cell viability of rat insulinoma 5F (RIN5F) cell lines over the treatment of plant extract was assessed by 3-(4,5-dimethyl-2-thiazolyl)2,5-diphenyltetrazolium bromide assay. The insulin-releasing effect was evaluated by insulin secretion assay over RIN5F cell lines by enzyme-linked immunosorbent assay.

Results: The ethanolic extract of the roots of R. madagascariensis Sonn. showed negligible cytotoxicity at $20-40 \mu \mathrm{g} / \mathrm{ml}$, and hence, concentrations up to $40 \mu \mathrm{g} / \mathrm{ml}$ were used in insulin secretion assay. The ethanolic root extract at 20 and $40 \mu \mathrm{g} / \mathrm{ml}$ significantly ( $<<0.05$ compared to control) stimulated the insulin release in a dose-dependent manner even in the presence of glucose at lower and higher concentrations (5 and $10 \mathrm{mM}$ ).

Conclusion: Thus, our results validate its traditional claim in the treatment of diabetes by stimulating the secretion of insulin, thereby suggesting a possible mechanism of its antidiabetic effect.

Keywords: Insulin secretagogue, Rat insulinoma 5F, Diabetes, In vitro, Ravenala, Insulin secretion assay, Cytotoxicity.

(C) 2019 The Authors. Published by Innovare Academic Sciences Pvt Ltd. This is an open access article under the CC BY license (http://creativecommons. org/licenses/by/4. 0/) DOI: http://dx.doi.org/10.22159/ajpcr.2019.v12i2.29011

\section{INTRODUCTION}

Diabetes mellitus is a metabolic disorder showing levels of high blood glucose due to improper insulin secretion or insulin activity or both [1]. In 2013, it was found to be 382 million people affected with this chronic disorder and the data estimated will be 592 million by 2035 [2]. The current treatment demands a chronic management with oral hypoglycemic agents that carry a burden of adverse effects and drug resistance $[3,4]$. Market available peroxisome proliferatoractivated receptor-gamma agonists to minimize insulin resistance and meglitinides that stimulate insulin secretion, and glucagon-like peptide- 1 analog exenatide and dipeptidyl peptidase-IV inhibitors have been nowadays preferred by the diabeticians [5].

The mechanism of antidiabetic activity of the most drugs of natural origin suggests the stimulation of insulin release from pancreatic beta-cells [6]. In the reported literature, various plant extracts including Capparis zeylanica [6], Gymnema sylvestre [7], Caulerpa lentillifera [8], Gynura procumbens [9], Ficus deltoidea [3], and Abutilon indicum [4] were explored for their insulin secretagogue activity in beta-cell lines.

Ravenala madagascariensis Sonn. of family Strelitziaceae commonly known as Traveller's palm has been traditionally used for diabetes [10]. The successive ethanolic extract of the leaves of R. madagascariensis Sonn. was reported to exhibit significant antidiabetic [11], hypolipidemic [12], renoprotective [12], and antioxidant [13] activity against alloxan-induced diabetic rats. The aim of the present study is to identify whether the ethanolic extract of the roots of R. madagascariensis Sonn. has the potential to elevate the insulin secretion without exhibiting the deleterious effects on beta-cell viability.

\section{METHODS}

\section{Cell lines}

Rat insulinoma 5F (RIN5F) cell lines were used in the study. RIN5F cell lines were obtained from the National Centre for Cell Science, Pune. The cells were maintained in Dulbecco's modified Eagle's medium supplemented with $10 \%$ fetal bovine serum, penicillin $(100 \mathrm{U} / \mathrm{ml})$, and streptomycin $(100 \mu \mathrm{g} / \mathrm{ml})$ in a humidified atmosphere of $50 \mu \mathrm{g} / \mathrm{ml} \mathrm{CO}_{2}$ at $37^{\circ} \mathrm{C}$.

Collection and authentication of plant material

Roots of $R$. madagascariensis Sonn. were collected from Kochi, Kerala (Fig. 1), during a fine dry weather and dried under shade for 3 weeks. The plant was identified and authenticated by Plant Anatomy Research Centre (PARC), Chennai. A voucher specimen (PARC/2017/3572) has been reserved in the Department of Pharmacognosy, SRM College of Pharmacy, Chennai.

\section{Extraction of plant material}

The shade dried and coarsely powdered roots of $R$. madagascariensis Sonn. were macerated with ethanol for 5 days with intermittent shaking. The ethanolic extract obtained on maceration is then filtered, concentrated to dryness and the percentage yield was calculated. Preliminary phytochemical screening was carried out to detect the phytoconstituents present in the extract using standard phytochemical methods [14].

\section{Cell viability assay}

The cytotoxic effect of $R$. madagascariensis Sonn., root extract on RIN5F cell lines, was determined by 3-(4,5-dimethyl-2-thiazolyl)2,5-diphenyltetrazolium bromide (MTT) assay [15]. The cells were seeded in a 96-well plate at a density of $1 \times 10^{5} /$ well and incubated at 
$37^{\circ} \mathrm{C}$ in the presence of $5 \% \mathrm{CO}_{2}$. A fresh medium was replaced at the end of $24 \mathrm{~h}$. Varying concentrations of ethanolic root extract were prepared and transferred to the cells in the 96-well plate. After $48 \mathrm{~h}$ of incubation, $100 \mu \mathrm{l}$ of MTT solution containing $5 \mathrm{mg} / \mathrm{ml}$ MTT bromide in physiologically balanced solution was added and the mixture was incubated for $4 \mathrm{~h}$ at $37^{\circ} \mathrm{C}$ after which the medium was removed, and the formazan crystals formed by the living cells were dissolved in 100 $\mu \mathrm{l}$ of dimethyl sulfoxide. The absorbance was measured at $570 \mathrm{~nm}$. The assay was carried out in triplicate. The percentage of cell viability was calculated using the following formula:

$\%$ Cell viability $=\frac{\mathrm{A} 570 \text { of treated cells }}{\mathrm{A} 570 \text { of control cells }} \times 100$

Graphs are plotted using the percentage of cell viability at Y-axis and concentration of the sample in X-axis. Cell control and sample control were included in each assay to compare the complete cell viability.

\section{Insulin secretion assay}

RIN5F cell lines were seeded in 24-well plates at $2 \times 10^{5}$ cells/well and incubated at $37^{\circ} \mathrm{C}$ and $5 \% \mathrm{CO}_{2}$. After $24 \mathrm{~h}$ of incubation, the cells were washed twice with excess medium containing glucose at lower and higher concentrations. The cells were incubated at $37^{\circ} \mathrm{C}$ for $3 \mathrm{~h}$. Glucose-induced insulin secretion assay of ethanolic root extract at 20 and $40 \mathrm{mg} / \mathrm{ml}$ was also studied in the presence of glucose at lower $(5 \mathrm{mM})$ and higher $(10 \mathrm{mM})$ concentrations. The aliquots in all wells were collected to determine the concentration of insulin in the media by enzyme-linked immunosorbent assay kit [16].

\section{Statistical analysis}

Data are expressed as mean \pm standard error of the mean of triplicates. Statistical comparison between groups was done by one-way ANOVA

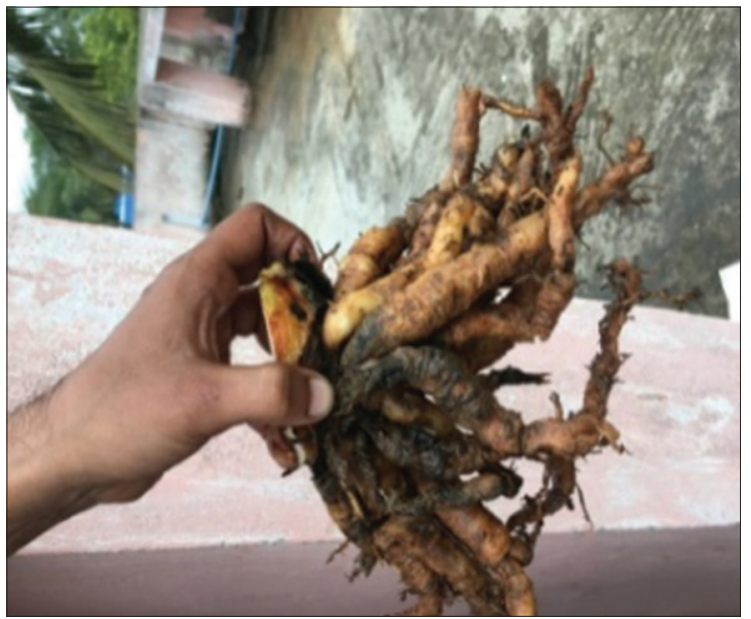

Fig. 1: Root - Ravenala madagascariensis Sonn. followed by Tukey-Kramer multiple comparison tests to analyze the difference. Statistical significance was considered when $p<0.05$.

\section{RESULTS}

The maceration of the powdered roots of R. madagascariensis Sonn., with ethanol yielded a semisolid yellowish extract, and the percentage yield was found to be $12.8 \% \mathrm{w} / \mathrm{w}$. The preliminary phytochemical screening of the root extract showed the presence of carbohydrates, flavonoids, alkaloids, glycosides, phenols, tannins, steroids, saponins, and proteins (Table 1).

To assess the non-cytotoxic concentration of $R$. madagascariensis Sonn., the viability of RIN-5F cells was evaluated by treating increasing concentrations of root extract at dose ranging from 0 to $10,000 \mu \mathrm{g} / \mathrm{ml}$ using MTT assay.

Within the tested concentration, the root extract showed a negligible cytotoxicity between 20 and $40 \mu \mathrm{g} / \mathrm{ml}$ (Figs. 2 and 3), and hence, concentrations up to $40 \mu \mathrm{g} / \mathrm{ml}$ were used for the further insulin secretion assay.

The treatment of RIN-5F cells at 20 and $40 \mu \mathrm{g} / \mathrm{ml}$ with ethanolic root extract of R. madagascariensis Sonn. significantly increased the secretion of insulin as compared to the control (Table 2). Furthermore, a marked glucose-stimulated insulin secretary (GSIS) effect was observed in RIN-5F cells. We observed that GSIS was directly proportional to the concentration of glucose and dose dependently, a significant GSIS was observed at 20 and $40 \mu \mathrm{g} / \mathrm{ml}$ in low (5 ml) as well as high glucose medium $(10 \mathrm{ml})$.

\section{DISCUSSION}

Secondary metabolites from natural sources were proven as leads combating and treating various disease ailments [17]. A major chunk of the traditional medicinal system remains unorganized as people rely more on the local medicine men or Vaids in spite of the enormous commercially available herbals [18].

The current study has demonstrated that the ethanolic root extract of $R$. madagascariensis Sonn. possesses insulin secretagogue effect in the presence of glucose. The results in Table 2 exhibit the effect of ethanolic extract in stimulating the insulin release in vitro in a dosedependent manner. The insulin secretagogue effect of the ethanolic root extract of $R$. madagascariensis Sonn. was significantly higher at hyperglycemic conditions, and this, in turn, explains the role of $\beta$-cell glucose metabolism in insulin secretagogue activity of the extract [19].

Investigating the mode of action of glucose lowering agents by in vivo approaches is challenging. Hence in vitro insulin secretion assay on RIN $5 \mathrm{~F}$ cell lines, where the potential of the extract to stimulate the insulin secretion can be studied by its direct action on $\beta$ cells are carried out [7].

Table 1: Qualitative phytochemical screening of the ethanolic extract of the root of Ravenala madagascariensis Sonn.

\begin{tabular}{llll}
\hline S. No. & Plant constituents & Powdered plant material & Ethanolic root extract of Ravenala madagascariensis Sonn. \\
\hline 1 & Carbohydrate & + & + \\
2 & Flavonoids & + & + \\
3 & Glycosides & + & - \\
4 & Alkaloids & + & + \\
5 & Phenols & + & + \\
6 & Tannins & + & - \\
7 & Terpenoids & - & + \\
8 & Saponins & + & + \\
9 & Proteins & + & + \\
10 & Lipids & + & - \\
11 & Steroids & - & - \\
12 & Anthraquinones & - & \\
13 & Iridoid glycosides & - & + \\
\hline
\end{tabular}

+: Denotes the presence of phytoconstituent, -: Denotes the absence of phytoconstituent 
Table 2: Insulin release of the ethanolic root extract of Ravenala madagascariensis Sonn. on RIN5F cell line

\begin{tabular}{llll}
\hline Concentration of the extract & $\mathbf{0 ~} \mathbf{~ M}$ glucose $\mathbf{( p g / m l )}$ & $\mathbf{5 ~} \mathbf{~ m M ~ g l u c o s e}(\mathbf{p g} / \mathbf{m l})$ & $\mathbf{1 0 ~} \mathbf{~ M ~ g l u c o s e}(\mathbf{p g} / \mathbf{m l})$ \\
\hline Control & $60.83 \pm 0.059$ & $103.54 \pm 0.052$ & $135.59 \pm 0.088$ \\
$20 \mu \mathrm{g} / \mathrm{ml}$ & $164.45 \pm 0.197^{*}$ & $207.20 \pm 0.047^{*}$ & $257.52 \pm 0.216^{*}$ \\
$40 \mu \mathrm{g} / \mathrm{ml}$ & $196.43 \pm 0.121^{*}$ & $282.38 \pm 0.190^{*}$ & $307.28 \pm 0.072^{*}$ \\
\hline
\end{tabular}

Data are expressed as mean \pm SEM of triplicates $(n=3)$. Data were analyzed using one-way ANOVA followed by Tukey-Kramer multiple comparison test. ${ }^{*} \mathrm{p}<0.05$ compared to control. SEM: Standard error of the mean

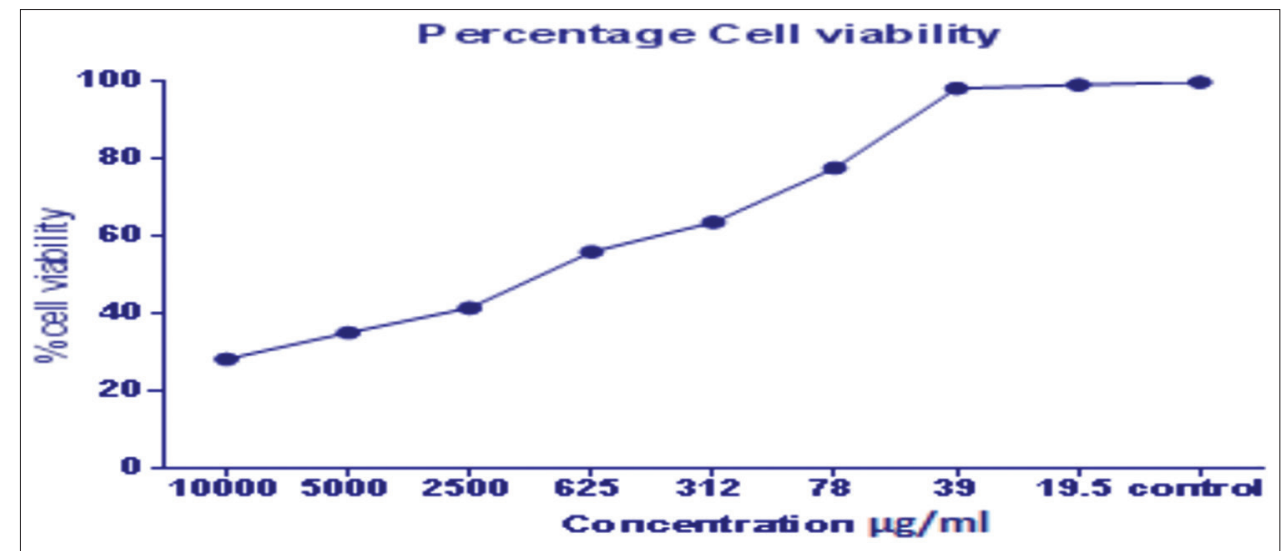

Fig. 2: Cell viability effect of ethanolic root extract of Ravenala madagascariensis Sonn. Data are expressed as mean \pm standard error of the mean of triplicates $(n=3)$. Data were analyzed using one-way ANOVA followed by Tukey-Kramer multiple comparison test. $p<0.001$ compared to control

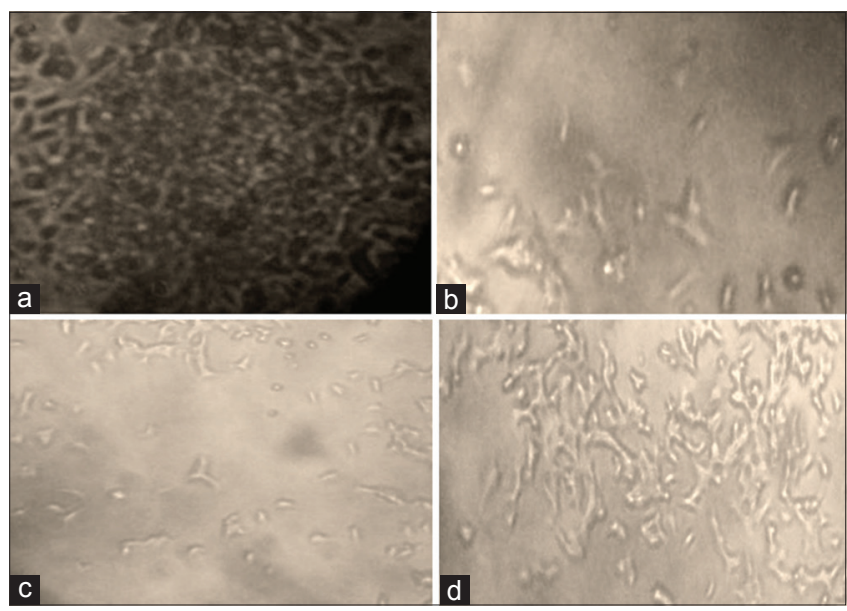

Fig. 3: Cell viability profile of ethanolic root extract of Ravenala madagascariensis Sonn. (a) Normal rat insulinoma 5F, (b) viability - 10,000 $\mu \mathrm{g} / \mathrm{ml}$, (c) viability $-1250 \mu \mathrm{g} / \mathrm{ml}$ (d) viability - $39 \mu \mathrm{g} / \mathrm{ml}$

Studies on the insulin secretion stimulating effect of G. sylvestre extract prepared by ethanol-sulfuric acid extraction and reported its insulinotropic effect from mouse insulinoma $6 \beta$ cells at $0.25 \mathrm{mg} / \mathrm{ml}$ [20]. Band et al. have studied the role of arachidonic acid as an effective insulin secretagogue formed in $\beta$-cells as a result of phospholipase A-2-mediated hydrolysis of membrane phospholipids in the presence of voltage-operated calcium channel inhibitor [21]. Sharma and Rhyu have reported the stimulated secretion of insulin in RIN cells and an enhanced glucose transporter expression and glucose uptake in 3T3 L1 adipocytes (derived from mouse embryonic fibroblast) [8].

The aqueous extract of $G$. procumbens as a hypoglycemic agent and the mechanisms involved were investigated by Hassan et al. and found that it can be due to reduced intestinal glucose absorption as a result of its high-fiber content $[9,22,23]$. Studies have been reported that the stimulation of insulin secretion and glucose absorption in a dosedependent manner by hydroalcoholic extract of saffron and the effect was even more pronounced at higher doses [24].

\section{CONCLUSION}

The findings of the present in vitro studies revealed that $R$. madagascariensis Sonn. ethanolic root extract showed antidiabetic activity by stimulating the insulin secretion from RIN5F cell lines. Further, investigations are under progress to identify the proper dose and role of the phytoconstituents of $R$. madagascariensis Sonn. on diabetic parameters at the molecular level.

\section{AUTHORS' CONTRIBUTION}

All the authors have contributed equally to the conductance of study, writing, and editing the article.

\section{CONFLICTS OF INTEREST}

None of the authors have any conflicts of interest to be declared.

\section{REFERENCES}

1. American Diabetes Association. Diagnosis and classification of diabetes mellitus. Diabetes Care 2013;36:S67-74.

2. International Diabetes Federation. International Diabetes Federation Diabetes Atlas. $6^{\text {th }}$ ed. Brussels, Belgium: International Diabetes Federation; 2013.

3. Adam Z, Khamis S, Ismail A, Hamid M. Ficus deltoidea: A potential alternative medicine for diabetes mellitus. Evid Based Complement Alternat Med 2012;2012:632763.

4. Krisanapun C, Peungvicha P, Temsiririrkkul R, Wongkrajang Y. Aqueous extract of Abutilon indicum sweet inhibits glucose absorption and stimulates insulin secretion in rodents. Nutr Res 2009;29:579-87.

5. Persaud S, Jones P. Beta-cell-based therapies for Type 2 diabetes. Eur J Endocrinol 2008;4:36-9.

6. Balekari U, Veeresham C. In vivo and in vitro evaluation of antidiabetic and insulin secretagogue activities of Capparis zeylanica. Pharmacol 
Pharm 2015;6:311-20

7. Liu B, Asare-Anane H, Al-Romaiyan A, Huang G, Amiel SA, Jones PM, et al. Characterisation of the insulinotropic activity of an aqueous extract of Gymnema sylvestre in mouse beta-cells and human islets of langerhans. Cell Physiol Biochem 2009;23:125-32.

8. Sharma BR, Rhyu DY. Anti-diabetic effects of Caulerpa lentillifera: Stimulation of insulin secretion in pancreatic $\beta$-cells and enhancement of glucose uptake in adipocytes. Asian Pac J Trop Biomed 2014:4:575-80.

9. Hassan Z, Yam MF, Ahmad M, Yusof AP. Antidiabetic properties and mechanism of action of Gynura procumbens water extract in streptozotocin-induced diabetic rats. Molecules 2010;15:9008-23.

10. Amala S. Traditional Medicines for Modern Times: Antidiabetic Plants. Boca Raton: CRC Press; 2008. p. 26.

11. Priyadarsini SS, Vadivu R, Jayshree N. In vitro and In vivo antidiabetic activity of the leaves of Ravenala madagascariensis Sonn., on alloxan induced diabetic rats. J Pharm Sci Technol 2010;2:312-7.

12. Priyadarsini SS, Vadivu R, Jayashree N. Hypolipidaemic and renoprotective study on the ethanolic and aqueous extracts of leaves of Ravenala madagascriensis Sonn., on alloxan induced diabetic rats. Int J Pharm Sci 2010;2:44-50

13. Priyadarsini SS, Vadivu R, Vijayalakshmi A, Kumar PR. Antioxidant activity of Ravenala madagascriensis Sonn., leaves on alloxan induced diabetic rats. Int J PharmTech Res 2013;5:1823-7.

14. Harborne JB. Phytochemical Method: A Guide to Modern Techniques of Plant Analysis. $2^{\text {nd }}$ ed. London, New York: Chapman and Hall; 1973. p. 4-34.

15. Plumb JA, Milroy R, Kaye SB. Effects of the $\mathrm{pH}$ dependence of 3-(4,5-dimethylthiazol-2-yl)-2,5-diphenyl-tetrazolium bromideformazan absorption on chemosensitivity determined by a novel tetrazolium-based assay. Cancer Res 1989;49:4435-40.

16. Arya A, Looi CY, Cheah SC, Mustafa MR, Mohd MA. Anti-diabetic effects of Centratherum anthelminticum seeds methanolic fraction on pancreatic cells, $\beta$-TC6 and its alleviating role in Type 2 diabetic rats. J Ethnopharmacol 2012;144:22-32.

17. Abdurrazak M, Rao MU, Ado AB, Mohd KS, Zin T. Some natural products and their secondary metabolites attributed towards diabetic cure: A review. Int J Pharm Pharm Sci 2015;7:22-8.

18. Dimple, Kumar A, Kumar V, Tomer V. Traditional medicinal systems for treatment of diabetes mellitus: A review. Int J Pharm Pharm Sci 2018;10:7-17. Available from: https://www.innovareacademics.in/ journals/index.php/ijpps/article/view/25374/14653.

19. Latha M, Pari L, Sitasawad S, Bhonde R. Insulin-secretagogue activity and cytoprotective role of the traditional antidiabetic plant Scoparia dulcis (Sweet broomweed). Life Sci 2004;75:2003-14.

20. Persaud SJ, Al-Majed H, Raman A, Jones PM. Gymnema sylvestre stimulates insulin release in vitro by increased membrane permeability. J Endocrinol 1999;163:207-12.

21. Band AM, Jones PM, Howell SL. Arachidonic acid-induced insulin secretion from rat islets of langerhans. J Mol Endocrinol 1992;8:95-101.

22. Akhtar MS, Iqbal J. Evaluation of the hypoglycaemic effect of Achyranthes aspera in normal and alloxan-diabetic rabbits. J Ethnopharmacol 1991;31:49-57.

23. Frati-Munari AC, Gordillo BE, Altamirano P, Ariza CR. Hypoglycemic effect of Opuntia streptacantha lemaire in NIDDM. Diabetes Care 1988:11:63-6.

24. Dehghan F, Hajiaghaalipour F, Yusof A, Muniandy S, Hosseini SA, Heydari $\mathrm{S}$, et al. Saffron with resistance exercise improves diabetic parameters through the GLUT4/AMPK pathway in-vitro and in-vivo. Sci Rep 2016;6:25139. 